\title{
Artigo \\ Demandas, direitos e entendimentos da "Justiça": um estudo de caso \\ da sociedade escravista do \\ Império do Brasil ${ }^{1}$
}

\author{
Luiz Alberto Couceiro \\ Universidade Federal do Maranhão
}

\begin{abstract}
RESUMO: Nesse texto analiso um caso, ocorrido em 1872 e localizado em um processo criminal, em que escravos da fazenda Monte Verde, em São Fidélis (Rio de Janeiro), mataram e esquartejaram o feitor livre e administrador Tertuliano Guerra. Sustento o argumento de que os escravos estavam cientes de que ir à "Justiça", entregando-se após cometer um crime de morte, era recurso interessante para constranger seu senhor na esperança de terem suas reivindicações atendidas, suas questões judicializadas. Aqui, utilizo como estratégia analítica a interpretação de outros tipos de situações nas quais escravos tenham percebido que usar a justiça era um caminho interessante para fazerem valer seus direitos, inscritos em leis, e não somente os consuetudinários.
\end{abstract}

PALAVRAS-CHAVE: Trabalho escravo e justiça, crime, direito e controle moral, Antropologia da escravidão.

Nos últimos 15 anos, localizei 35 processos criminais no Arquivo Nacional (Rio de Janeiro) nos quais os acusados são escravos oriundos das Províncias do Norte do Império do Brasil, principalmente de Pernambuco. ${ }^{2}$ Os processos são concernentes a 1850 , que marca o final do tráfico internacional de escravos para o Brasil e a intensificação do tráfico interprovincial para as Províncias do Sul, até 1888. As tentativas de homicídio e os 
homicídios, objetos das acusações, tiveram como alvo administradores e feitores, e ocorreram no âmbito do trabalho em fazendas de café de diversos portes das províncias do Rio e de São Paulo. Opero com a hipótese de que as relações nessas fazendas, envolvendo escravos, senhores, administradores e feitores, fossem regidas por "acordos implícitos", que se fundariam na tradição local e compreenderiam um conjunto de obrigações recíprocas, não judicializadas, e se assemelhariam aos acordos que Sigaud (2007, 2004, 1999) identificou, com base em pesquisa etnográfica nas grandes plantações canavieiras da Zona da Mata de Pernambuco, em período mais recente. As tentativas de homicídio e os homicídios mencionados nos processos poderiam ter ocorrido através de uma ruptura dos "acordos implícitos".

Sempre que utilizar a palavra "Justiça", entre aspas e com a inicial em maiúscula, estarei me referindo aos recursos legais oficiais fornecidos, direta ou indiretamente, pelas instâncias do Estado Imperial aos escravos, libertos, africanos livres e livres. O artigo revisitado por Cunha (2009: 133-156) mostra-se ainda importante referência para oxigenar novas reflexões e formas de se compreender fontes judiciais, principalmente quando distingue o direito praticado do direito da letra da lei para tratar de casos de alforria de escravos que eram ou não revogadas por seus senhores. Isso mostra ser imprescindível observar os contextos de acionamento ou sua recusa dos recursos jurídicos, não somente sobre a ação de senhores, como também em relação às demandas de escravos e as questões relativas ao processo de juridicialização das mesmas.

Os referidos processos criminais, ainda, simbolizam um momento a partir do qual as demandas dos escravos passavam a ser conformadas no âmbito da "Justiça". Eles insistiram nesse ponto, via de regra, ao longo de seus depoimentos. Avaliar as possíveis conexões entre as atitudes costumeiras e o que as tornava crime era tarefa de quem detinha mais poder dentro das fazendas, revelando as relações entre senhores, seus prepostos, trabalhadores livres (quando houvesse) e os escravos, bem como o nível que colocaria em termos de importância e aplicação das punições legais contra o que se entendia como um rompimento das obrigações.

Nesse sentido, as definições de Weber (1997: 170-192) acerca de autoridade do tipo tradicional e suas formas de legitimação me auxiliam na análise do caso. Isso porque procuro levar em consideração a diversidade e o peso de fatores racionais e afetivos, mesmo sem procurar operar com essa dicotomia, no entendimento do processo de relações de dominação e subordinação envolvendo os agentes sociais em questão. O papel desempenhado pelo senhor seria um exemplo aproximado do que Weber analisou. Esse 
papel está informado pelas dinâmicas diversas de formas de dominação. A partir da ideia de "poder tático ou organizacional”, de Wolf (2003: 325-343), avalio que os agentes sociais que analiso operavam suas reivindicações pelo que entendiam por direitos e recurso à "Justiça". Isso necessariamente passava pela desigual distribuição de poder e direitos jurídicos sobre regras de trabalho nas fazendas e a regulação da vida dos trabalhadores escravizados, dados centrais para compreender quais informações constituíam o repertório de ação de escravos, senhores e seus prepostos. ${ }^{3}$

De modo algum quero com isso dizer que os escravos haviam decorado um conjunto de leis formuladas pelos agentes competentes do Estado Imperial, no intuito de balizar suas ações organizadas de protesto e negociação acerca das condições de trabalho na fazenda com o senhor. Não é novidade o uso dos processos judiciais nos estudos sobre a sociedade escravista no Brasil, principalmente no século XIX (por exemplo: Azevedo, 1999, 2010; Castro, 1998; Chalhoub, 1990; Couceiro, 2003; Franco, 1969; Grinberg, 1994; Guimarães, 2006a, 2006b; Lara, 1988; Machado, 1994, 1987; Wissenbach, 1998). Nessas investigações, pesquisadores vêm mostrando um aumento considerável da abertura de processos criminais envolvendo escravos, a partir de 1850, em fazendas de café de diversas envergaduras, localizadas no Oeste Paulista e no Vale do Paraíba fluminense (Castro, 1998; Machado, 1994, 1987). Diversas razões colaboraram para isso. O viés analítico adotado de modo algum procura encaixar os casos à análises que confirmariam o funcionamento, na prática, da burocratização da legislação do Império no que tangia às acusações de homicídio ou tentativas de homicídio por parte dos escravos.

Como a legislação não amarra as relações sociais estabelecidas, é necessário atravessar esse campo interpretativo, testando outras possibilidades de reflexão sobre os usos, as lógicas e as versões de atitudes e condutas - redimensionadas e redefinidas - como partes de processos de criminalização e institucionalização de códigos, regras (judicialização) e comportamentos entendidos como sendo "naturais" ou ofensivos a um determinado grupo ou pessoa. Thompson (1987) demonstrou, em relação às 50 atitudes e condutas criminalizadas punidas com a pena de morte por enforcamento com a promulgação da "Lei Negra" a partir de maio de 1723 na Inglaterra, que nem sempre uma lei produzida por grupos da elite econômica, burocrática e política tem a garantia de ser usada a favor de seus interesses. A análise de processos de disputa por causas bem localizadas conformadas na justiça do direito legal pode revelar formas de os agentes sociais especializados nos usos das leis causarem reveses aos interesses de pessoas com maior acesso aos meios de dominação pela via judiciária. ${ }^{4}$ 
Gluckman (1965) leva a discussão para a comparação entre o direito dos Barotse e o direito romano, em termos de suposta filiação a estágios da evolução histórica. Contudo, outra parte de suas análises implica em avaliar a centralidade das relações complexas entre o papel de direitos de pessoas, coisas e obrigações para a compreensão do funcionamento das transações não apenas legais. As obrigações e contra-obrigações, as dívidas entre as partes interessadas em acordos devem ser levadas em consideração para a compreensão dos desdobramentos das interpretações de justiça e direitos dos envolvidos. Portanto, é necessário levar em conta as discrepâncias de status social dessas pessoas diante dos recursos jurídicos, inclusive, assim como procuro fazer com escravos, senhores e seus prepostos. Por outro lado, Bohannan (1957) é contrário a comparações apressadas entre formas distintas de compreensão social de justiça, ainda mais se ligadas a processos históricos distintos. As ideias sobre direitos e dívidas dos Tiv e as suas práticas jurídicas são analisadas pelo autor, reforçando suas diferentes naturezas e as conexões entre si. ${ }^{5}$ Em minhas pesquisas, escravos e senhores, esses últimos em larga medida, não eram juristas, mas dizer que não tinham entendimentos do que pudesse representar a "Justiça" em suas vidas já é outra história. Ao contrário da generalidade jurídico-cultural de Gluckman, Bohannan observou o caráter localizado de usos do aparato jurídico entre os Tiv para responder satisfatoriamente às suas demandas. Nesse sentido, interessa-me compreender as querelas que em alguma medida constituíam os conflitos de entendimento de direitos e justiça no universo de relações da fazenda do caso em questão face ao plano geral de relações judicializadas entre aqueles agentes sociais.

A construção de acusações e defesas, tanto em termos de estratégias dos agentes envolvidos como em termos do modo como encaram os códigos legais estabelecidos como molduras limitadoras de suas ações, também pode e deve ser explorada. As formas de obediência de empregados aos seus superiores em hierarquias de poder estabelecidas e socialmente reconhecidas por todos os que fazem parte de um cenário de disputas, como no caso de quem era escravo, trabalhador livre, mas empregado, e senhor informam as ações processuais jurídicas, do início ao fim dos processos que analisei. Informam as formas de tratamento, as linguagens e as possibilidades de formulação de estratégias de cada participante, acusados e acusadores. Arendt (1999) deixou isso claro ao argumentar como o tenente-coronel nazista Adolf Eichmann se comportava diante de seus acusados e inquiridores em todo o processo sobre sua participação no comando de parte da logística do holocausto. A autora mostra como o acusado reconhecia seu desempenho no processo como parte de sua situação de trabalho, cumprindo ordens para as quais foi treinado - 
o que em nada o isentava de responsabilidade por seus atos, e que também não é o que estou enfatizando. Arendt buscava organizar o entendimento acerca de suas respostas não serem nem "mentirosas" e/ou "cínicas", mas sim reveladoras de formas de perceber o mundo e nele viver. Isso vale para todos os depoentes em processos jurídicos, que, como fontes de investigação, passam por considerações de ordem social de traduções de discursos falados para folhas de papel, em meu caso. Muito embora não seja algo problematizado em termos epistemológicos na literatura produzida no Brasil, os depoimentos de escravos nos tribunais devem ser entendidos, porém não engessados, sob os contornos dos cenários jurídicos que os envolvem Zaeck (2003).

Conforme demonstrado por Chalhoub (2003) e Carvalho (2007), o Imperador Dom Pedro II havia, dentro de sua estratégia de conduzir a abolição da escravidão no Brasil até o início dos anos 1870, firmado compromisso com ministros de países como Inglaterra, principalmente, e Espanha, para de fato se empenhar em fiscalizar a aplicação da Lei Eusébio de Queiróz, promulgada em $1850 .{ }^{6}$ Rodrigues $(2005,2000)$ examinou os debates e a aplicação eficaz dessa lei, que proibia a entrada de escravos no país, com o maior incremento do aparato burocrático policial e judiciário. Azevedo (1987) avaliou que havia também ações administrativas, relativas ao incentivo da maior vigilância sobre a circulação de escravos. Ainda segundo a mesma autora, medidas foram adotadas, em posturas municipais, motivadas, dentre outros fatores, pelo medo dos senhores e políticos de regiões cafeeiras das províncias do Rio e de São Paulo de que a alta concentração de escravos pudesse levar à eclosão de grandes insurreições, aos moldes da de Santo Domingo, das cidades de Nova York e Salvador, com ameaças à sua vida e à de seus familiares. ${ }^{7}$

Ao interpretar processos criminais do perfil referido, considero que a segunda metade do século XIX não foi palco, necessariamente, do aumento de insurreições e planos de insurreição de escravos no Sudeste cafeeiro. Penso que a mera existência desses registros não permite afirmar se houve ou não um aumento das ações criminalizáveis de escravos, em relação ao período anterior a 1850. Os conflitos ocorridos nas fazendas poderiam simplesmente não ter sido levados ao âmbito da "Justiça", muito menos terem gerado de processos judiciais. A discussão acerca dos motivos para isso ter acontecido é assunto para outro texto. Fato é que, após 1850, acusações de assassinato, e tentativas de assassinato, de escravos contra senhores e seus empregados livres foram encontradas noutras fontes, como jornais e correspondências privadas e confidenciais entre autoridades policiais e judiciais, delegados e ministros de Estado, e não geraram processo criminal. Assim, prefiro afirmar algo que possa demonstrar com mais segurança por meio da análise dos processos 
criminais envolvendo escravos como acusados de homicídio, ou tentativa de homicídio, de feitores e administradores no âmbito do trabalho em fazendas das regiões do café.

Não é de hoje que avaliações sobre as conexões entre direito, elites políticas e burocráticas no Império do Brasil, e as suas atitudes diante de como entendiam ações criminalizadas dos escravos, vêm sendo produzidas no país (por exemplo: Beiguelman (1973: 9-42), Lamounier (1988), Grinberg (1994; 2002), Mendonça (1999), Pena (2001). O que perpassa esses autores, que utilizam os mais diferentes métodos e enfoques teóricos, é a ideia de que membros da burocracia do direito na sociedade escravista imperial estavam envolvidos por preocupações e discussões acerca do final ou continuação desse regime de trabalho e de concepção de sociedade no Brasil. Embora nem sempre enfatizadas, as atitudes de escravos no âmbito das regras de trabalho fazem parte das preocupações dessa literatura. Minha opção é pela ênfase nisso, uma vez que no presente artigo examino um caso de conflito entre escravos, seu senhor e seus prepostos, segundo a hipótese de que suas demandas podiam ser conformadas por meio do recurso à "Justiça", a partir de 1850. Essa hipótese ancora-se na de que escravos estavam desenvolvendo meios de recorrer às instâncias legais, sabendo que em alguma medida poderiam obter sucesso, reconhecendo os agentes aos quais deveriam se aliar. Aqui, analiso as narrativas de um conflito (envolvendo mortes) entre escravos e agentes disciplinares numa mesma fazenda, discutindo o papel das percepções envolventes, e os sentidos e os significados que os cativos conferiam às suas próprias condutas.

No campo da historiografia, stricto sensu, há duas posições importantes sobre o possível aumento ou não de crimes cometidos por escravos contra seus senhores e seus prepostos nas fazendas cafeeiras do Rio e de São Paulo. Ambas operam a partir do comércio interno e do final do comércio internacional de escravos, e de seus efeitos diversos, a partir de 1850. Por um lado, Florentino e Góes (1997) argumentam que aqueles senhores teriam controlado os tipos de arranjos familiares entre os escravos de grupos por eles identificados como sendo distintos entre si, mostrando, dessa maneira, terem consciência de como procurar garantir a paz, isto é, poucos conflitos mortais, entre seus escravos. Por outro, Slenes (1999) observa como uma suposta "cultura" (segundo o autor, uma maneira de conferir significado às experiências individuais e coletivas) referencial comum entre esses escravos teria alavancado justamente maior mobilização para se unirem ao redor de objetivos semelhantes, como, por exemplo, lutarem por condições objetivas de vida não oferecidas pelos seus senhores. Nesse artigo, não opero com nenhuma das duas posições, propondo outro tipo de abordagem para o mesmo cenário, por meio de um 
estudo de caso - algo bem menos abrangente do que os dois estudos acima citados, além de partir de outras discussões que vão além da historiografia.

\section{Mataram, comeram a leitoa e se entregaram: o caso da fazenda Monte Verde (São Fidélis, 1872)}

Natural da Corte do Império do Brasil (Rio de Janeiro), Bonifácio era escravo de José Augusto de Figueiredo Côrtes. Estava com 20 anos de idade e há oito residia na fazenda de café Monte Verde, em São Fidélis, município localizado na província do Rio de Janeiro. Era acusado de ser o autor da morte do feitor da mesma fazenda. Segundo seu depoimento, que consta no processo judicial instaurado para apurar esse fato, às três horas da tarde do dia 16 de setembro de 1872, “em pleno trabalho de roça”, estavam ele e "seus demais parceiros sendo feitorizados por Tertuliano Guerra quando este castigou todos os escravos" (Arquivo Nacional, doravante AN, Corte de Apelação, Processo Criminal número 88, maço 161, galeria $\mathrm{C}$, ano 1873, fl.12). Bonifácio, que havia voltado para a casa de morada, foi novamente para a roça e, lá chegando, também foi "castigado pelo feitor em um dos olhos". Caiu logo após ter recebido o golpe. Em seguida, o feitor dirigiu-se para Laurindo, outro escravo do grupo. Laurindo "gritou que acudissem Bonifácio que estava atordoado com as dores provocadas pelas pancadas recebidas do feitor" (Idem, fl. 12v). Quando Bonifácio voltou o olhar para seus companheiros, não viu mais o feitor. Foi até onde estavam todos e "encontrou o corpo do feitor Tertuliano Guerra [já morto] todo ensanguentado, e com os olhos perfurados". Por isso, não soube dizer às autoridades que tomavam seu depoimento "quem foi que deu as pancadas no feitor", bem como a ordem de sucessão dos fatos que redundaram em sua morte. Bonifácio apenas "admitiu que o feitor fora assassinado por todos os escravos” (Idem, fl. 12v).

Apesar de todo o ocorrido, "os escravos continuaram trabalhando na roça com as cavadeiras de plantar milho", as quais, segundo explicou Bonifácio, eram um "pau pontiagudo que se finca no chão e se põe o milho". Os escravos "seguiam a ordem do feitor", que, antes do ocorrido, "pressionava-os para que a tarefa fosse cumprida num certo ritmo e tempo por ele determinados". Depois disso, "voltaram, no final da tarde, para a casa de morada da fazenda - como sempre faziam". Lá chegando, foram interpelados pela esposa do feitor "que perguntou onde estava seu marido". "Responderam que Tertuliano Guerra havia ficado na roça” (Idem, fl. 13). 
Enquanto "Bonifácio soltava os animais que estavam presos", "seus parceiros mataram uma leitoa". "Prepararam e comeram" o animal na senzala. Assim, já estavam devidamente supridos para a longa caminhada até a delegacia mais próxima, "onde foram se apresentar como autores da morte do feitor" (Idem, fl. 13).

O cadáver foi "encontrado pelas autoridades policiais com os olhos furados". Em seu depoimento, Bonifácio afirmou que “depois de os escravos se retirarem da roça ninguém mais foi lá", e que ele também "não viu e nem sabia quem fez os tais furos nos olhos do feitor" (Idem, fl. 13v). Ele não indicou um culpado em especial e também não negou que algum dos escravos pudesse ter cometido o assassinato. Nada do que aconteceu "fora combinado", segundo ele. Todos os escravos teriam tomado, ao mesmo tempo, "a atitude de avançar no feitor e golpeá-lo com as cavadeiras de plantar milho". Isso porque o feitor, "muito irritado", teria "partido para golpeá-lo como castigo" (Idem, fl. 13v).

Ainda segundo Bonifácio, depois de acontecido o suposto crime, o escravo Vicente teria tido o cuidado de "levar para longe da roça o cavalo do feitor", deixando-o "lá amarrado". Por fim, teria corrido a informação de que alguém ouvira algum dos escravos dizer que "se [o feitor] Guerra voltasse a maltratá-los eles iriam assassiná-lo" (Idem, fl. 14). Bonifácio afirmou, ainda, que "fora Miguel, homem livre, vendedor de leite, e ele os autores dos furos nos olhos do feitor" (Idem, fl. 14).

Sem saber informar sua idade, mas presumindo ter por volta de 45 anos, o "escravo de nação" - leia-se, nascido na África - Laurindo disse que há seis estava em Monte Verde - portanto, dois a menos que Bonifácio - e que há quatro Tertuliano Guerra era feitor e administrador da fazenda. Laurindo confirmou que "o feitor havia sido assassinado pelo grupo de escravos" (Idem, fl. 15). Segundo sua versão, os escravos teriam "assassinado o feitor no dia 16, depois das três horas da tarde, a cacetadas, com as próprias cavadeiras de pau com as quais plantavam milho". Laurindo creditou o assassinato ao fato de "Tertuliano Guerra tê-lo castigado". "Quando gritou aos demais escravos que o acudissem, seus companheiros primeiro esbordoaram o feitor, tendo sido Tiburcio o primeiro a descarregar a cacetada, seguido pelos demais que continuaram mesmo depois de terem percebido que o feitor já estava morto" (Idem, fl. 15v).

Laurindo afirmou que "Tiburcio e Bonifácio teriam instruído os escravos para, depois de voltarem da roça, soltar os animais" e caso encontrassem a esposa do feitor "dizer-lhe ele havia ido a um lugar chamado Botija, como era de seu costume, e que em breve deveria estar de volta". O conjunto de instruções ainda incluiria a morte, o preparo e 
o consumo de uma leitoa, antes de "seguirem para se entregar à Justiça, na delegacia mais próxima" (Idem, fl. 15v). No caminho, "Bonifácio havia lhes dito que não comprometessem uns aos outros e que, quando lhes fosse perguntado sobre o ocorrido, todos deveriam assumir igual culpa, sem que tivesse havido premeditação nem combinação alguma para o assassinato do feitor, sendo, assim, um ato de momento" (Idem, fl. 16). Em troca, Bonifácio teria "prometido aos escravos" que, se assim o fizessem, "todos ficariam livres de qualquer punição da Justiça ou do senhor". Laurindo ainda afirmou que "Tertuliano Guerra fora morto por Bonifácio", tal como este o havia acusado.

Tiburcio foi ouvido no dia 30 de setembro, afirmando ser africano, com 50 anos de idade, escravo do mesmo senhor há 15, e o mais velho da fazenda Monte Verde. Afirmou que havia uma "combinação entre os escravos para matar o feitor, e que estes se aglutinavam ao redor de sua liderança". A atitude dos escravos foi devida aos "maus tratos que o feitor, também administrador da fazenda, lhes dava, privando-os dos domingos e dias santos, exigindo muito serviço, pouca roupa e pouca comida” (Idem, fl. 17). Segundo Tiburcio, o "desejo de todos os escravos era dar um basta nesses seus sofrimentos, acabando com Tertuliano Guerra" (Idem, fl. 17). O papel de Tiburcio foi, então, o de viabilizar "a vontade e o desejo dos escravos, organizando um plano para não serem presos nem muito menos punidos por ninguém, de maneira que cada detalhe fosse pensado como uma forma de "dar recados" ao senhor e às autoridades da Justiça" (Idem, fl. 17v). Desta maneira, teriam se reunido, na noite anterior ao assassinato do feitor, na senzala, especialmente para que Tiburcio mediasse uma espécie de assembléia geral para combinarem como executariam cada etapa do plano que ainda estava sendo traçado.

O plano, segundo Tiburcio, era o seguinte: "quando um dos escravos gritasse me acudam!", (...) “todos os outros escravos cobririam Tertuliano Guerra com suas próprias cavadeiras". Na ocasião em que fora castigado, Laurindo deu o grito combinado e Tiburcio foi o primeiro a se precipitar com sua cavadeira sobre o feitor, seguido dos demais escravos, que teriam desferido seguidas bordoadas.

Outro escravo, Miguel, africano, de 50 anos de idade, relatou os fatos de maneira idêntica à versão de Tibúrcio, e ainda afirmou, sobre a ideia de os escravos matarem o feitor, que "essa combinação fora feita mais de dois meses antes de ser realizada, e que só estavam aguardando a melhor ocasião" (Idem, fl. 18).

A única diferença em relação aos dois depoimentos anteriores que encontrei está no do escravo André, de 26 anos de idade, "crioulo" (leia-se, nascido no Brasil). Trata-se do fato de que Bonifácio seria o "feitor negro da fazenda". Para André, ele estava investido 
da "confiança do senhor", com margem de manobra no acesso às regras de punição e justiça por ele recomendadas aos seus empregados.

Barnabé, escravo de 50 anos de idade, também nascido na África, frisou, em seu depoimento, "a fome que tomava conta dos escravos, que por isso mesmo mataram uma leitoa para comerem após a morte do feitor” (Idem, fl. 24). Para ele, o feitor era quem impedia "a melhor alimentação dos escravos". Continuando, afirmou que, "antes do feitor assumir também a função de administrador da fazenda, muitas vezes os escravos se alimentavam com leitoas, porcos e galinhas". Foi por isso que, uma vez não sendo mais impedidos pelo feitor, "prepararam a leitoa e a comeram na senzala, antes mesmo de se entregarem". Ainda segundo o experiente escravo Barnabé, "um dos motivos que levaram os escravos a escolher aquele dia para matar Guerra foi por não terem almoçado nem jantado, visto que a comida nesse dia foi pior do que o de costume" (Idem, fl. 24v).

Esse fato fez-se presente no depoimento do escravo Desidério, de 30 anos de idade. Afirmou que no dia 16 de setembro, "uma escrava foi até a plantação levar-lhes a comida". (...) "Por ser pior do que o jantar da noite anterior, que não haviam comido, também não comeram esta refeição" pois, "ao contrário do costume, o angu estava dentro de um barril, o feijão por cima, com fubá semeado e talos de carne”. (Idem, fl. 22)

No dia 17 de outubro, Laurindo deu às autoridades responsáveis pela investigação uma versão mais detalhada dos acontecimentos. Na manhã do dia 16 de setembro, “depois de Tertuliano Guerra deixar bem claro que puniria todos os escravos, fosse na senzala, fosse na roça, caso achasse necessário”, teria ouvido Tiburcio conversando com André. O "tom da conversa" havia lhe chamado tanta atenção que foi "conferir do que se tratava". Tiburcio havia dito a André, e repetiu a Laurindo, que "aquilo era demais e que, se fossem castigados naquele dia, eles dois haveriam de matar o feitor". A conversa logo acabou quando da chegada do escravo Vicente. Tiburcio e André haviam deliberado em segredo que, naquele dia, "o plano" seria posto em prática. Laurindo contou que, "na véspera, Bonifácio disse-lhes que o feitor iria naquele dia à roça vigiar os escravos e, se preciso fosse, os castigaria". Para o depoente, Bonifácio havia feito isso porque, "como feitor negro, não confiava mais nos métodos de Tertuliano Guerra para lidar com os escravos".

Pouco tempo depois de chegarem à roça, ainda segundo Laurindo, "o feitor Tertuliano Guerra os castigou". Mais tarde, o feitor "deu relhadas em Bonifácio - no momento em que este trabalhava e feitorizava simultaneamente os parceiros na plantação de milho - furando-lhe um dos olhos". Em seguida, "desceu para onde estava Laurindo e deu-lhe uma lambada pelas costas", provocando o imediato grito de "o que é isto!". Ferido, 
Laurindo "desandou a correr, levando um golpe na cabeça com as costas de uma foice, dado pelo próprio feitor". Logo em seguida, ambos "atracaram-se". Nesse momento, "vieram Tiburcio e André". O primeiro, "deu uma pancada na cabeça do feitor", que, em seguida, "foi largado por Laurindo"; o segundo "desferiu outro golpe, também na cabeça do feitor, com uma cavadeira de ferro". Em seguida, Tertuliano "caiu morto". Os escravos "endireitaram-no de modo a parecer que estivesse dormindo, continuando o trabalho na roça de milho e, depois, voltando, na hora de costume, para a senzala".

Laurindo admitiu essa atitude, muito embora em seu depoimento não conste que tenha golpeado o feitor. Sua culpa circunscrevia-se no grito que, mesmo sentindo a dor da pancada, conseguiu dar como o sinal combinado entre ele, André e Tiburcio para que daquele dia em diante não mais aturassem as regras impostas pelo feitor e administrador da fazenda. Daí, toda a esperada ação teria sido iniciada.

Em 26 de novembro, Tiburcio, André e Laurindo foram condenados a galés perpétuas, ou seja, prisão com trabalhos forçados, sem a apelação ter sido aceita. Os três foram enquadrados no artigo 192, relativo ao crime de homicídio, do Código Criminal que entrou em vigor em de 15 de dezembro de 1830. Somente em 1886 os açoites foram abolidos como pena aos escravos. Como o artigo 179, \ XIX, da Constituição de 1824, abolia açoites, tortura, marca de ferro quente e demais penas cruéis, cabia somente condenar os escravos aos açoites (Malheiro, 1944: 27). Os outros réus foram absolvidos. Aquele artigo do Código Criminal previa como condenação, no grau máximo, a pena de morte. Entretanto, sabe-se que a regulamentação da punição dos escravos que tentassem envenenar, matar ou ferir gravemente seus senhores, administradores das fazendas e feitores, bem como seus familiares, só ocorreu com a lei permanente $\mathrm{n}^{\mathrm{o}} 4$, de 10 de junho de 1835 - que acabou valendo até o final do Império. A pena capital não era comumente aplicada, ocorrendo com frequência sua comutação para a de açoites e galés perpétuas (Malheiro, 1944: 29-31). 


\section{As demandas dos escravos e o envolvimento da "Justiça"}

Provocar a investigação policial, mesmo quando realizada sob os auspícios senhoriais, e a instauração do processo jurídico, poderia ser uma chance de escravos constrangerem e pressionarem seu senhor a tomar conhecimento e atender suas reivindicações - ou parte delas. Isso poderia ocorrer em um momento crítico, limite, na relação dos escravos com os feitores e administradores. Tal situação eclodia em atitudes mais radicais, a partir, por exemplo, da opinião predominante nos grupos de escravos acerca de um conjunto de decisões postas em prática, em sequência, pelos prepostos e que fazia com que se sentissem ofendidos. O limite do aceitável poderia ser marcado através das habilidades argumentativas dos líderes do grupo, no caso aqui analisado os escravos mais antigos na fazenda, mas não os mais velhos em idade. Foram eles, ao que parece, que tiveram maior competência na construção e na apresentação dos argumentos a fim de convencer os demais escravos a tomarem atitudes mais contundentes contra os feitores e/ou administradores.

Identifiquei semelhanças entre os casos pesquisados em fontes de arquivo produzidas no século XIX e os que foram relatados e analisados nas etnografias elaboradas por Sigaud (1977). Essa autora demonstrou como trabalhadores nos engenhos de açúcar da Zona da Mata pernambucana, a partir de 1960, compreendiam o momento de recorrerem às instâncias judiciais, e através de que meios, para conseguirem fazer valer o que entendiam serem seus “direitos”. Isso ocorria mesmo durante a Ditadura Militar (1964-85), nos vários períodos de judicialização das relações de trabalho no campo. Em outro texto, Sigaud (1996) apresentou em detalhes o processo histórico de construção da legislação concernente ao trabalhador rural e como este a usava em situações de maior conflito com os donos dos engenhos e seus empregados. Parte da minha estratégia de pesquisa coincide com a da autora: localizar momentos em que esses trabalhadores recorreram à "Justiça", e sob quais demandas e estratégias procuravam judicializá-las.

Para os escravos, as etapas do processo criminal, sempre iniciado pela denúncia cada vez mais aceita pelas autoridades policiais e judiciais, a partir dos anos 1850, mesmo se também fossem feitas por escravos -, e seguida pelo inquérito, introduziam outro elemento na sua relação com o senhor: a "Justiça". Tratava-se de uma instância com força socialmente reconhecida como sendo superior ao senhor e aos seus prepostos, uma vez que seus representantes tinham autoridade para chamá-los para depor, prestar esclarecimentos, multar o senhor, vender seus bens, incluindo os escravos. Juízes, 
promotores, advogados, chefes de polícia, delegados, inspetores de quarteirão e policiais, o que chamo por agentes da "Justiça", assim identificada em vários depoimentos de escravos nos processos criminais pesquisados, eram capazes de impingir constrangimentos ao senhor e seus prepostos, através de regras e mecanismos próprios que extravasavam aqueles que faziam parte das relações estabelecidas nas fazendas. Durante o processo judicial era possível que o senhor tivesse que se justificar diante de algum ou alguns desses agentes, esclarecendo suas atitudes frente a interpelações, tais como: Por que não demitiu aquele feitor? Se sabia do descontentamento dos escravos, o que havia feito para resolver o problema? E, até mesmo, por que havia deixado de pagar certos impostos? Além disso, o senhor era obrigado a apresentar um advogado por ele escolhido para se reportar aos juízes e representar os escravos e a si mesmo na condução da argumentação própria à burocracia jurídica.

Se os escravos condenados foram dois africanos e um brasileiro, Tiburcio, Laurindo e André, respectivamente, indicando que os encarregados do julgamento não discriminaram os réus pela origem, o líder do plano teria sido um africano. Os depoimentos dos réus unanimemente apontaram o africano Tiburcio, escravo mais antigo da fazenda, como aquele que teria influenciado os escravos a executar o que ele havia planejado. Ele teria contado com a indignação do "feitor negro" Bonifácio, que cuidava da disciplina do trabalho dos escravos na roça ao mesmo tempo em que com eles trabalhava. Ser africano em si não queria dizer nada, não seria problema e nem solução, mas de algum modo ser africano e o mais velho dos escravos na fazenda pode de alguma forma ter influenciado na conquista do respeito dos demais escravos e no reconhecimento de sua liderança. O resultado do processo tratou de afastá-lo do grupo, para sempre, alijando-o de sua influência para organizar outras ações de reivindicação.

Bonifácio indicou que não mais se entendia com o feitor Tertuliano Guerra, desde o momento em que este passou a também exercer a função de administrador da fazenda. Seu depoimento deixou clara sua indignação em relação às mudanças que o "feitor livre" vinha promovendo e que atingiam a dinâmica da vida dos escravos: a qualidade e a quantidade dos alimentos servidos nas refeições, a ausência das folgas, os castigos físicos considerados injustos e desmedidos e a quantidade de roupas disponibilizada. Por tudo isso, os réus deixaram claro que não legitimavam e não mais aceitavam a autoridade do feitor livre e administrador da fazenda. Talvez eles tivessem querido deixar claro ao senhor qual o tipo de feitor livre e administrador, funções acumuladas ou não por uma mesma pessoa, que seria por eles aceito. 
Havia situações nas quais as maneiras que os senhores conduziam os negócios de suas fazendas eram postas à prova pelas experiências cotidianas dos seus trabalhadores escravizados. Ser escravo não significava qualquer tipo de submissão total e completa às suas vontades. Critérios de honra estariam envolvidos nas relações com os empregados senhoriais, aqueles que conduziam a vida do dia-a-dia em certas fazendas, que lidavam face a face com os escravos, tendo que decidir quais critérios de julgamento da sua disciplina e regras de punição adotariam. Alguém arcava com as consequências dessas ações. Em alguma medida, os escravos estavam medindo a reputação do senhor, mostrando a ele em um ambiente externo à fazenda que não sabia escolher um feitor e um administrador. O que estava em jogo era a disputa entre os critérios que eles achavam ser os mais adequados para que o senhor fizesse tal e qual opção, e os do senhor.

No caso das fazendas que venho pesquisando, as questões giravam em torno de demandas claras nas regras do trabalho, expostas no âmbito da "Justiça" pelos escravos em seus depoimentos. Nesses, assumiam seus crimes como um recurso viável para a demonstração de sua insatisfação, para se fazerem ouvidos. E os escravos das roças vinham descobrindo que recorrer à "Justiça" era um recurso a mais do que aqueles relativos às relações pessoalizadas constituídas nas fazendas. Daquela maneira, envolviam como árbitro de suas questões outros agentes sociais que não aqueles altamente subordinados à autoridade do seu senhor. Porque à "Justiça" os escravos nada deviam. Trata-se, aqui, de um esforço para localizar e interpretar, por meio de fontes manuscritas produzidas pelo poder judiciário imperial, aquilo que, do ponto de vista dos indivíduos, pode conferir sentido à sua vida. Isso poderia ocorrer por meio de condutas por eles sabidas como passíveis de serem criminalizadas, através de denúncia, investigação e punição ou absolvição judiciais.

Nessa última questão, sigo as pistas deixadas pelo documento publicado por Reis e Silva (1989), intitulado Tratado proposto a Manuel da Silva Ferreira pelos seus escravos durante o tempo em que se conservaram levantados (c. 1789). ${ }^{8}$ Trata-se de uma carta redigida a rogo de um grupo de escravos do senhor Manoel da Silva Ferreira, por volta de 1789, na província da Bahia, na qual reivindicavam questões relativas ao trabalho que faziam. Esses escravos afirmavam não quererem "guerra”, mas sim "paz", sendo que isso estava condicionado à reação do senhor acerca daquelas reivindicações. Dentre elas, havia a solicitação de não serem enviados ao trabalho de "pescar mariscos", pois para isso o senhor poderia "mandar seus pretos Minas", além de não mais aceitarem os "atuais feitores", pedindo que o senhor fizesse a "eleição de outros" com a aprovação dos escravos. Por fim, queriam poder 
"brincar, folgar e cantar em todos os tempos que quise[ssem], sem que [fossem impedidos] e nem precis[assem de] licença". Esse documento mostra como havia distinções de status de trabalho construídas pelos escravos de um mesmo senhor. Por outro lado, permite perceber que as demandas apresentadas pelos escravos não se amparavam na legislação vigente e não tinham, portanto, garantias jurídicas. Só poderiam ser contempladas no âmbito de um "acordo implícito" com o senhor.

Volto ao ponto das alianças entre escravos de origens distintas. Antes, algumas palavras sobre as origens ditas étnicas de escravos tema em geral dos mais debatidos nas recentes pesquisas sobre as sociedades escravistas nas Américas e no Caribe. Oliveira $(1995 / 1996)$ demonstrou que os segundos nomes seguidos de um primeiro nome de origem cristã nos registros de escravos comercializados para o Brasil não mostravam o seu grupo de origem na África. Eles também não revelavam sua autoidentificação em alguma das etapas do comércio de escravos. Farias, Soares e Gomes (2005) sugeriram que batismos coletivos de escravos produziam nomes e segundos nomes registrados em alguns documentos de compra e venda e até apreensão de escravos. Esses batismos ocorriam com frequência ainda nas feitorias na Costa da África, momentos antes do embarque para o Brasil. As classificações pelos nomes de nações africanas (como Mina, Angola, Jeje, Moçambique etc.) faziam parte da classificação burocrática, parte dos instrumentos técnicos utilizada pelos agentes participantes da burocracia do tráfico de escravos durante as negociações. Não raro grupos de escravos e autoridades policiais das várias regiões do Império utilizavam aqueles nomes para elaborar sua classificação, segundo critérios outros que não os do tráfico internacional - como tipo de falares, trejeitos corporais, roupas, moradias e crenças religiosas, por exemplo, como argumentou Parés (2006) para a relação entre os escravos classificados como sendo Jeje, em Salvador, e as práticas rituais religiosas denominadas candomblé, na segunda metade do século XIX. ${ }^{9}$

O caso que analiso não permite, em minha avaliação, qualquer tipo de análise por meio da caracterização da origem "étnica" dos escravos. Ao menos não com os dados concernentes ao processo criminal e à fazenda onde trabalhavam e viviam. Contudo, seguindo as estratégias de Wood (1996) em seu livro sobre a insurreição ocorrida em Stono, pondero que a origem de grupos sociais e seus componentes deva ser um dos elementos levados em consideração - mesmo que não venha a ser o mais enfatizado nas investigações. ${ }^{10}$ Dois escravos africanos e outro nascido no Brasil foram condenados. O grupo de escravos que se entregou à "Justiça" era composto por ambas diferentes origens. O juiz talvez tenha refletido sobre qual deles devesse ser afastado da fazenda, para 
evitar mais acontecimentos daquele tipo. Embora eu não tenha conseguido informação alguma sobre a fazenda e o senhor, observei pela leitura do processo que o senhor não estava presente pessoalmente na condução de seus negócios na fazenda, delegando essa função a um empregado livre. ${ }^{11}$ Não raras são as vezes que encontro nos documentos informações de que senhores de escravos das províncias do Rio e de São Paulo não permaneciam longos períodos em suas fazendas. Passavam boa parte do tempo nas capitais (Rio e São Paulo), porque era lá que se travavam os debates a respeito da mão-de-obra escrava e da localização da malha ferroviária para o escoamento da produção. Era ainda lá que se reuniam com os exportadores e que participavam dos leilões de escravos (Cf. Marquese, 2004: 259-298).

$\mathrm{Na}$ ausência dos senhores, cabia aos administradores a gestão do cotidiano das fazendas. A administração da disciplina do trabalho e dos castigos exemplares era de responsabilidade do feitor, homem de confiança do senhor e muitas das vezes indicado pelo administrador (Ver Lara, 1988: 57-96). O feitor poderia ser um trabalhador livre, um escravo ou um liberto, encarregado de dar ritmo ao trabalho dos escravos e verificar se eles o estavam executando da forma por ele considerada como sendo adequada. Em não raros casos, era ele quem definia qual escravo, por que e como seria punido. Isso poderia ter efeitos os mais diversos de acordo com a opção da organização do trabalho nas fazendas, se por grupos (gangs) ou por indivíduos, se por produção diária ou semanal previamente combinada com o senhor ou o administrador. Nesse sentido, os escravos avaliavam sua margem de movimentação para empreendimentos pessoais e coletivos, desde o cultivo de roças próprias, até mesmo a venda desses produtos em núcleos urbanos próximos. ${ }^{12}$

Tendo como base depoimentos de viajantes europeus e documentos privados de senhores de Vassouras, província do Rio de Janeiro, e municípios cafeeiros próximos, Stein (1990: 174-175) concluiu que o pequeno proprietário, ao contrário do fazendeiro próspero, "dirigia pessoalmente seus trabalhadores do campo, residia em alojamentos despretensiosos, quase tão simples quanto o dos escravos", mantendo-os até mesmo como parte da família, comendo do mesmo tipo e qualidade de alimento. Talvez percebendo em alguma medida situação desse tipo, os escravos de Monte Verde somente chamariam a atenção do senhor para as suas insatisfações informando outros agentes com poder para convocá-lo e obrigá-lo a escutar as suas versões do que andava ocorrendo na fazendo e tomar ciência das possíveis consequências de sua ausência na condução dos negócios internos à mesma. A vigilância era pessoal e realizada através do olhar sobre os trabalhadores - daí inúmeras fazendas terem em comum a presença do feitor livre e do 
feitor negro, escravo de confiança do senhor. Ele deveria, em suma, trabalhar com seus parceiros na roça e intermediar a relação dos mesmos com o administrador e algumas vezes até mesmo com o senhor. Essa seria a função de Bonifácio.

Segundo seu próprio depoimento, Bonifácio teria furado os olhos do feitor. Só posso especular o significado dessa atitude. O feitor negro tirou a visão do feitor livre, sentido fundamental nos trabalhos de vigilância e punição exercidos pelo feitor e administrador. Os fatos que ambos esses feitores observavam, desde o momento em que Tertuliano Guerra também acumulou o trabalho de administrador, não eram por eles percebidos da mesma forma. Esse último talvez interpretasse comportamentos dos escravos da roça como sinais de indolência. Embora Bonifácio tenha afirmado que não tivesse havido "premeditação do grupo" quanto à morte do de Tertuliano Guerra, em seu depoimento o africano Laurindo o contestou. Se no primeiro depoimento disse que Bonifácio, nascido no Brasil, não teria sido o mentor de parte do plano para matar o feitor e administrador, assim como da versão que deveriam contar à "Justiça", em seu segundo depoimento atribuiu a Bonifácio a liderança do planejamento e do ocorrido. Laurindo quem sabe não reconhecesse a autoridade de Tiburcio, africano, escravo mais velho na fazenda, o bastante para ver a possibilidade de ter capitaneado, sozinho, a morte do feitor.

O juiz do caso solicitou somente a Laurindo um novo depoimento, no qual este afirmou que teria ouvido uma combinação entre Tiburcio e André para matar o feitor. Ambos esses escravos, mais Bonifácio, o feitor negro, seriam assim os líderes do plano e da ação, segundo essa nova versão. Para as autoridades, o perfil dos escravos acusados era: o mais velho e talvez mais influente na fazenda, Tiburcio, africano; o feitor negro, função importante na mediação entre os escravos, o feitor e administrador e o senhor, Bonifácio, nascido no Brasil; um escravo novo e nascido no Brasil, que teria ajudado de forma decisiva no plano de matar o feitor, demonstrando ser fiel aos outros dois escravos figuras proeminentes no grupo e no funcionamento de negociações e acordos na fazenda. Porém, no lugar do feitor negro, quem compôs o trio de condenados foi o próprio Laurindo.

A pena de galés perpétuas, à qual Tibúrcio, André e Laurindo foram condenados, obrigava os escravos a andarem sozinhos ou em grupo, algemados pelo pé e ainda carregando corrente de ferro presa ao pescoço em uma gargantilha. Geralmente, eram assim encaminhados para trabalhos públicos na província onde o crime tivesse sido cometido (Cf. Código Criminal do Império do Brazil annotado com os atos dos poderes Legislativo, Executivo e Judiciário, que têm alterado e interpretado suas disposições desde que foi publicado, e com o 
cálculo das penas em todas as suas aplicações por Araújo Figueiras Júnior [Bacharel em Direito], $2^{\mathrm{a}}$. edição cuidadosamente revista e aumentada com os atos dos Poderes supra-referidos, expedidos depois da 1ª Edição, Rio de Janeiro, Eduardo e Henrique Laemmert, 1876, Parte I, Título 2, Artigo 44.). O julgamento teria sido, então, decidido a partir do segundo depoimento de Laurindo, com a "Justiça" definindo que o feitor negro continuaria na fazenda. Dela estariam afastados permanentemente o escravo mais velho e africano, seu comparsa nascido no Brasil e mais outro africano que contou nova versão às autoridades, rompendo com a anterior que dava mais consistência à ideia de que todos os escravos do grupo haviam executado o feitor e administrador. Em momento algum no processo há qualquer tipo de argumentação sobre o fato de os demais escravos da fazendo não terem sido condenados. Após o segundo depoimento de Laurindo, o caso foi encerrado.

Stein (1990) analisou casos em que a estratégia de senhores afastarem escravos considerados causadores de problemas aparece em depoimentos escritos pelos próprios senhores, cartas ou diários com recomendações sobre a administração de fazendas, deixadas para filhos, netos e em alguns casos esposas. Em seis de outubro de 1858, o proprietário da fazenda Monte Alegre, Francisco de Lacerda Werneck escreveu ao seu comissário na Corte, pedindo que vendesse seu escravo Ambrósio. "Carpinteiro de primeira classe, machadeiro e trabalhador do campo, com saúde de ferro”, dizia Werneck, vinha lhe trazendo transtornos porque "se recusa[va] a trabalhar para [ele]" (Carta de Francisco P. de Lacerda Werneck para Bernardo Ribeiro de Carvalho, Fazenda Monte Alegre, seis de outubro de 1858, AN, documentos relativos à família Werneck, apud. Stein, 1990: 173). A Baronesa de Paty do Alferes afirmou, certa vez, ter decidido "transferir nosso escravo Ciro porque ele é influência perniciosa na manutenção da boa disciplina" (Relatório do Estado da Nossa Casa desde seis de dezembro de 1861 até seis de dezembro de 1862, 104, verso, no Inventário, 1862, do falecido Barão do Paty, tendo como testamenteiro Francisco de Assis e Almeida, Cartório do Primeiro Ofício de Vassouras, apud. op. cit.). Zeferina das Chagas Werneck decidiu vender um escravo de sua fazenda por ser ele "insubordinado". Além do mais, ele não "queria mais trabalhar e poderia servir de mau exemplo aos outros escravos" (Inventário, 1875, do falecido João Barbosa dos Santos Werneck, tendo como testamenteira Zeferina das Chagas Adelaide Werneck, Fazenda São Luís de Massambará, Cartório do Primeiro Ofício de Vassouras, apud. op. cit.).

O mesmo autor, ainda, perscruta registros de que em certas ocasiões escravos consideravam que seriam melhor tratados na cadeia, se fossem condenados, do que nas 
fazendas de seus senhores. Em 15 de julho de 1877, o jornal vassourense O Município noticiou haver "uma crença errônea de que sob a penalidade de 'pena de galés' perpétuas, que é quase sempre imposta para crimes de escravos, a existência do escravo é menos áspera do que aquela que eles suportam sob propriedade privada" (Apud. Stein, 1990: 176, e também localizado na Biblioteca Nacional, doravante BN, Setor de Periódicos. A notícia tem como título "A Condenação de Escravos"). $\mathrm{Na}$ opinião de alguns jornais de municípios cafeicultores com grande concentração de escravos, estes vinham se rendendo voluntariosamente à polícia após assassinarem o feitor da fazenda onde trabalhavam. Para aquele mesmo jornal, em sete de outubro de 1877, eles “confessavam o crime com desdém cínico e tranquilamente aguardavam a inevitável condenação" (op. cit.: 176). Isso explicava o porquê de, naquele mesmo mês, por exemplo, o escravo Faustino, pertencente “ao Dr. Antonio José Fernandes, ter matado o seu feitor com uma podadeira, tendo se rendido" logo em seguida (op. cit.: 176). Diante de tais informações, visualizei outra possível interpretação para o depoimento de Laurindo e o desfecho do julgamento.

Havia outros universos de relações de confiança e perda de confiança no que concernia a punições no âmbito do trabalho entre senhores, seus prepostos e escravos que apontam situações próximas às que analiso. Oliveira (1988), Nabuco (1995) e, de forma mais contundente, Bello (1938: 43-46), mostram, através de exemplos, o contraponto daquela atitude senhorial tida como mais severa pelos escravos com outra, supostamente compreendida por eles como sendo benevolente, por parte dos senhores de engenho e usinas de açúcar em Pernambuco e Alagoas, no século XIX: na administração das normas de trabalho, nos esclarecimentos constantes aos escravos das regras de punição e das instruções dadas e reforçadas aos feitores e administrados para a sua devida execução.

Laurindo contou, em seu segundo depoimento, que Tiburcio teria outorgado a si mesmo a responsabilidade pela morte do feitor e administrador, encerrando de uma vez por todas a insuportável onda de castigos considerados por ele injustos, a comida inadequada e a falta de folgas. Antes mesmo de sua morte, o feitor e administrador havia prometido que em breve puniria, mais uma vez, todo o grupo de escravos. Laurindo, então, afirmou ter tomado parte no plano secreto de matar, naquele dia, o feitor e que suas ações não teriam comprometido o combinado De fato, com sucesso, os escravos mataram o feitor. Laurindo e Tiburcio eram escravos africanos, mais velhos, e colocados, nessa versão, no leme das ações contra o feitor. André era um escravo nascido no Brasil, jovem, mais forte, com mais disposição física, necessário e fundamental comparsa para a eficácia na execução do combinado. 
Com seu segundo depoimento, Laurindo teria protegido seus parceiros. tendo a coragem de assumir a culpa da precipitação do assassinato, ao mesmo tempo em que teria conseguido um lugar para ser mais bem tratado do que vinha sendo na fazenda. Teria também sido arrojado ao liderar o arranjo para a execução do que era há dois meses comentado entre os escravos. Seguindo este raciocínio, teria conseguido deixar intocada pela "Justiça" a importante figura de Bonifácio, o "feitor negro", canal de comunicação, legitimado pelo senhor, entre o feitor e administrador da fazenda e o grupo de escravos.

Para sustentar essa versão, que talvez tivesse convencido as autoridades da "Justiça" a encerrarem o processo judicial, é fundamental examinar algumas das afirmações feitas pelo escravo "crioulo" Desidério, de 30 anos de idade, sobre a atitude de Tiburcio. Desidério não contou em seu depoimento quais dos escravos especificamente teriam sido os autores do plano para matar o feitor. Sua versão dos fatos fora confirmada tanto pelo depoimento do escravo Miguel, um africano de 30 anos de idade, quanto pelo do escravo Barnabé, também africano. Desidério afirmou que "logo que chegaram à senzala, Tiburcio lhes disse que todos deveriam se ajudar, pois o crime tinha se dado na presença de todo o grupo" (AN, Corte de Apelação, número 88, maço 161, galeria C, ano 1873, fl. 44). Portanto, os escravos africanos do grupo de réus denunciados pela "Justiça" afirmaram que sob a liderança de dois escravos africanos, Laurindo e Tiburcio, todos os demais assumiriam a culpa pelo assassinato do feitor e administrador. Todos foram ao amanhecer até à delegacia para se entregar à "Justiça". Tiburcio teria argumentado, contra a opinião dos escravos que tentaram resistir ao seu plano, que as "autoridades iriam buscar na fazenda todos aqueles que não tivessem se entregado". Desta forma, "seria mais eficaz para os escravos que fossem juntos, contando a mesma versão dos fatos” (op. cit.: fl.44).

A partir das informações contidas no processo, não há indícios de que línguas, dialetos ou idiomas de origem africana ou outros códigos culturais, que teriam motivado relações baseadas no afeto entre pessoas de origem próxima, imigrantes, enfim, mesmo que por força, de uma mesma região da África, tenham configurado forças motrizes para a união entre "escravos africanos". Os depoimentos mostram que, ao menos segundo a versão de Laurindo e a de Desidério, alguns escravos africanos mantiveram a mesma versão dos fatos e que esta acabou sendo a aceita pela "Justiça". Ao fim e ao cabo, essa minha segunda hipótese para o desfecho do processo criminal indica que: o feitor negro teria sido mantido na fazenda, a maior parte dos escravos seguiu suas vidas em Monte Verde, os condenados teriam saído desta para um lugar onde pudessem, aos seus olhos, ter melhor tratamento. Tudo isso, repito, é pensado através de algumas das evidências 
apontadas noutras fontes acerca da percepção de escravos, senhores e agentes da "Justiça" sobre as atitudes dos primeiros.

Ambas as formas de entender o desfecho do processo criminal apontam para a judicialização das demandas dos escravos, que localizariam na "Justiça" formas de encaminhá-las com algum sucesso.

\section{Conclusão}

Uma vez não tendo amparo legal em termos de "Justiça", os escravos acusados de terem matado feitores e administradores das fazendas não teriam suas reivindicações por ela aceitas. Afinal de contas, não eram considerados como indivíduos, pessoas, a não ser na condição de réus, em termos legais, para encaminharem suas demandas e terem-nas ouvidas, investigadas e julgadas. Entendo que as ações dos escravos na fazenda Monte Verde eram protestos desencadeados como uma reação às mudanças nas regras do jogo da dominação senhorial, por meio das ações de seus prepostos. Eles podem ser aproximados de outros protestos de trabalhadores que também se originaram em rupturas de uma ordem tradicional, como ocorre nos estudados por Thompson (1971), Hobsbawm e Rudé (1982) e Moore Jr. (1967). A imagem do senhor inatingível, a não ser por fugas e pela formação de quilombos - categoria, diga-se de passagem, criminalizadora contida como rótulo no Código Criminal do Império -, não mais representava algo que não devesse ser enfrentado no âmbito da vida nas fazendas. Os escravos tinham alguma noção de que certas atitudes suas poderiam ser aceitas na "Justiça". Esta fazia isso por meio de regras que, dentre outras coisas, conformavam as atitudes senhoriais tomadas na administração de suas fazendas e na escolha de seus empregados livres ligados à disciplinarização e fiscalização dos escravos.

Weber me auxiliou a compreender o direito como códigos de condutas, limites e deveres esperados. As pessoas que estiverem de fora desse enquadramento sofrerão punições, por não corresponderem ao que está prescrito. Contudo, há processos de acusação e defesa das pessoas, e nisso Gluckman ajuda no entendimento de que elas agem com base no peso das consequências legais de suas atitudes. Essas ações podem ou não pertencer, em um primeiro momento, a relações legais do direito escrito em leis e códigos. Nesse sentido, Bohannan avalia a necessidade da ênfase nos cenários em que prestações e contraprestações ocorrem de maneira feliz ou com frustração de alguma parte, para a compreensão das formas de judicialização de contendas. Quando se analisam casos de 
forma mais aguda, sem ignorar as referências sociais gerais de seu enquadramento, podemse avaliar as desiguais distribuições e acessos à justiça e ao poder, como apontou Wolf (2003). Sigaud (1996; 1999; 2004), por sua vez, me levou a procurar perceber, no que Wolf chamou de "poder tático organizacional", quais os meios que trabalhadores empregam para envolver seus patrões em processos judiciais quando desejam reivindicar algum direito que não lhes tenha sido atendido. Afinal, ir à "Justiça" pode ser sinônimo de querer ser ouvido por algum árbitro externo à relação quando há o reconhecimento de repertórios desiguais de acesso ao campo jurídico.

Os indivíduos observados pela "Justiça" como representantes da ruptura com a dominação senhorial, como passando a ter vOz no âmbito legal, de forma direta, eram classificados por rótulos específicos, e logo estigmatizados: escravos vindos do Norte principalmente dos engenhos de Pernambuco ou da Bahia, com sua "tradição rebelde" e africanos, por exemplo. ${ }^{13}$ Procuro demonstrar como o processo de recusa de atitudes de dominação não consideradas mais como sendo legítimas pelos escravos nas relações com seus senhores, seus agentes da administração da disciplina do trabalho e das condições de existência na fazenda, ocorria obedecendo a formas estabelecidas de relacionamento nas fazendas.

Penso que há um antes e um depois da atitude julgada pelos escravos como sendo uma atitude limite da parte do feitor e do administrador sobre as relações no âmbito do trabalho. Antes, os escravos queriam um acordo direto, sem o envolvimento dos especialistas da "Justiça", mediando sua relação com o seu senhor e seus prepostos. A primeira opção geralmente era a negociação com o feitor e administrador, que poderia ser intermediada pelo feitor negro - um dos trabalhadores escravizados. Depois, quando o senhor visitava a fazenda, caso nela não morasse ou não estivesse com maior frequência presente, a ele se poderia recorrer. Quando o diálogo com o senhor não fosse bem sucedido, os escravos arranjavam uma forma de envolver o mediador externo, a "Justiça". E a forma mais eficaz disso ocorrer era assassinando o feitor livre e administrador, quando não, em casos mais radicais que encontrei na documentação, um familiar do senhor ou mesmo o próprio. Escravos, em alguns casos, como no que analisei aqui, reconheciam o papel desse novo elemento, dessa nova instância superior ao senhor, em algumas ocasiões práticas, na luta pelo que entendiam ser mais adequadas, menos sofridas condições de existência. 
${ }^{1}$ Esse artigo é resultado do pouco tempo que eu e Lygia Sigaud pudemos trabalhar juntos em meu pósdoutorado, realizado no âmbito do Programa de Pós-Graduação em Antropologia Social - Museu Nacional/UfrJ. Dedico a ela, em homenagem póstuma, esse artigo. Sem as conversas com Moacir Palmeira, Gilberto Velho (in memorian), Dale Tomich, Federico Neiburg, Fernando Rabossi, Benoît de L'Estoile, Rejane Valvano, Gustavo Onto, André Dumans Guedes e Pedro Silveira, e suas valiosas sugestões e críticas, esse artigo não teria sido possível. Agradeço a todos e os eximo de quaisquer responsabilidades sobre o texto. Quero registrar meu muito obrigado à ou ao parecerista da Revista de Antropologia pelas suas valiosíssimas sugestões, que muito melhoraram os argumentos que apresento, e as conexões entre antropologia e história através do direito. Sou muito grato às observações e correções de Pedro Lopes e Ricardo Regatieri pelo competente e gentil trabalho de revisão, uma etapa do aprendizado para tornar minhas ideias mais claras.

2 Aqui, não farei qualquer tipo de investimento em análise de cunho mais quantitativo. Pontos de vista atualizados sobre esse tipo de trabalho, que não contam com uma só forma de metodologia adotada, podem ser lidos, especificamente para o caso brasileiro, em Klein (2009). Sobre a importância das fontes oficiais para a investigação da presença de escravos oriundos das províncias do Norte que chegavam às fazendas de café nas do Sul, bem como desse fenômeno migratório compulsório e seus diversos efeitos na configuração social, ver Moura (1998: 153-182); Eisenberg (1977); Versiani (2000); Galloway (1968; 1971).

3 Para novas leituras de discussões específicas para relações entre senhor e escravo, estabelecidas pioneiramente por Genovese (1979) analisando as prestações e contraprestações entre esses dois tipos sociais no âmbito das relações de trabalho, ver Morris (1998).

${ }^{4}$ Há importantes comentários acerca desse estudo de Thompson, no âmbito de sua produção, que apontam para a sua originalidade historiográfica, e nos diálogos com parte da literatura antropológica, em Kaye e McClelland (1990). Sobre as influências metodológicas de Thompson nos já citados estudos da criminalidade escrava produzidos no Brasil, ver Lara (1995). Sobre as interpretações acerca da obra de Thompson por estudiosos da chamada história social no Brasil, ver provocativo artigo de Marquese (2013).

${ }^{5}$ Importantes apontamentos relativos aos argumentos de Bohannan e Gluckman acerca do direito podem ser encontrados de modo sistematizado em Oliveira (1992).

${ }^{6}$ Segundo Carvalho (2007: 130-136), desde pelo menos 1855 o Imperador demonstrava seu posicionamento contrário à manutenção da escravidão no Brasil. Nesse ano, em virtude de um desembarque ilegal de escravos africanos em Serinhaém, Pernambuco, Dom Pedro II apoiou as medidas tomadas por seu ministro da Justiça, Nabuco de Araújo, que mandou: invadir engenhos para localizar alguns daqueles escravos, processar seus donos e afastar três desembargadores da Relação de Pernambuco que haviam votado pela absolvição dos acusados. Seu repudio à escravidão também podia ser visto quando se recusava a conceder títulos de nobreza a traficantes de escravos.

7 Para informações e análises consagradas em relação ao caso da insurreição ocorrida em Salvador, ver Reis (2003). Em relação à que eclodiu em Santo Domingo, ver estudo clássico de James (2000) e o mais recente de Fick (1990); para o caso específico de Cuba, como contraponto do cenário caribenho mais geral, ver Scott (1991). No âmbito das leituras e orientações diversas ocorridas nos territórios escravistas localizados no Atlântico, ver Geggus (2001). Para as formas de repercussão desse evento no Brasil, ver Soares e Gomes (2002) e Gomes (2002). Avaliando o impacto das representações políticas desse evento no contexto da escravidão estadunidense, ver Clavin (2007) e suas considerações aprofundadas em Clavin (2010). Acerca da insurreição ocorrida nos EUA, ver, Aptheker (1966).

8 Tratado proposto a Manuel da Silva Ferreira pelos seus escravos durante o tempo em que se conservaram levantados (c. 1789), in Reis e Silva (1989: 123-124)

9 Operação semelhante à realizada por Parés para interpretar a formação do candomblé em Salvador foi executada por Reis (2003), Rebelião escrava no Brasil, sob a inspiração dos apontamentos de Barth (1998) sobre o conceito de "etnia", ao elaborar sua explicação acerca das condições de possibilidade na organização social para compreender a eclosão do levante dos Malês. Para o debate especializado acerca do tema no Brasil, são importantes referências: Parés (2005) e Slenes (1991/1992; 1995/1996). No cenário internacional, dentre outras, são relevantes referências: Mann (2001), Miller (2004). 
10 Para análise do mesmo evento, enfatizando a organização étnica dos envolvidos, ver Thornton (1991). Uma avaliação sobre as dimensões simbólicas e comportamentais da origem dos escravos africanos na configuração da sociedade escravista estadunidense pode ser encontrada em Morgan (1997).

11 Discussões recentes vêm sendo promovidas em relação às avaliações dos escravos quanto ao grau de influência que a pouca presença da figura física do senhor na fazenda provocava nas suas reivindicações de tratamento e também na possibilidade de fugirem com eficácia. Para reflexões acerca dessa temática, refirome a Marquese (2010).

12 Reflexões ainda inovadoras acerca da autonomia escrava encontram-se Machado (1988). O tema pode ser visto sob outra perspectiva, mais recentemente, em Faria (2007). Sobre as implicações das formas de organização do trabalho dos escravos, as consequências das relações entre eles e os senhores e seus empregados livres, e os graus de mobilidade que esses cenários de interação permitiam àqueles, ver Morgan (1988), Kaye (2008); os diversos artigos contidos em Berlin e Morgan (1991) e Tomich e Zeuske (2008). Atitudes senhoriais não são muitas vezes estudadas na historiografia pertinente no Brasil. Para uma referência pioneira e outra mais recente, ver, respectivamente: Silva (1984) e Lourenço (2010).

13 O termo "tradição rebelde" é usado por Reis (2003), em diversos momentos para avaliar a sequência de situações semelhantes em diversos aspectos, em Salvador e no Recôncavo da Bahia, que informavam politicamente o que ocorreu em janeiro de 1835. Uso os termos rótulo e estigma segundo conceituação de Goffman (1988), levando em consideração as ponderações de Becker (1974). Até que ponto africanos livres, escravos e libertos operavam as características que os rotulavam negativamente na interação com outros agentes sociais para conseguirem obter sucesso em suas empreitadas é o tema central de outro trabalho. Essa minha pesquisa foi elaborada para casos ocorridos na Corte, levado em consideração as características próprias das relações sociais em uma cidade escravista. Para situações ocorridas nas fazendas de café, ainda estou avaliando se e em que sentido é possível usar rótulo e estigma como conceitos sustentáveis com as fontes que tenho disponíveis.

\section{Referências bibliográficas}

APTHEKER, $\mathrm{H}$.

1966 Nat Turner's Slave Rebellion. New York, Grove Press.

ARENDT, $\mathrm{H}$.

1999 Eichmann em Jerusalém: um relato sobre a banalidade do mal. São Paulo, Companhia das Letras.

Azevedo, C. M. M. de.

1987 Onda negra, medo branco: o negro no imaginário das elites, século xix. Rio de Janeiro, Paz e Terra.

Azevedo, E.

2010 O direito dos escravos: lutas jurídicas e abolicionismo na provincia de São Paulo. Campinas, Editora da Unicamp.

1999 Orfeu de Carapinha: a trajetória de Luiz, Gama na imperial cidade de São Paulo. Campinas, Editora da Unicamp, Cecult. 
BARTH, F.

1998 "Grupos étnicos e suas fronteiras". In Poutignat, P. e Streiff-Fenart, J. Teorias da etnicidade. São Paulo, Editora da Unesp, pp. 185-227.

BECKER, Howard S.

1974 "Labelling theory reconsidered". In Rock, P. e McCintosh, M. (eds.), Deviance and social control. Londres, Tavistock, pp. 41-66.

Beiguelman, P.

1973 "O encaminhamento político do problema da escravidão no Império". In Pequenos estudos de Ciência Política, São Paulo, Pioneira, pp. 9-42, 2a . edição ampliada. BELLO, J.

1938 Memórias de um senhor de engenho. Rio de Janeiro, José Olympio.

Berlin, I. e Morgan, P. D. (eds)

1991 The slaves' economy: independent production by slaves in the Americas. Portland, Londres, Frank Cass.

BOHANNAN, P.

1957 Justice and judgement among the Tiv. Londres, Oxford University Press.

Carvalho, J. M. de

2007 D. Pedro II: ser ou não ser. São Paulo, Companhia das Letras.

Castro, H. M. M. de

1998 Das Cores do Silêncio: os significados da liberdade no Sudeste escravista, Brasil, Século XIX. Rio de Janeiro, Nova Fronteira.

Chalhoub, S.

2003 Machado de Assis, historiador. São Paulo, Companhia das Letras.

1990 Visões da Liberdade: uma história das últimas décadas da escravidão na Corte. São Paulo, Companhia das Letras.

Clavin, M. J.

2007 "American Toussaint: symbol, subversion, and the black Atlantic tradition in the American Civil War". Slavery and Abolition, n.28, v.1: 87-113.

Clavin, M. J.

2010 Toussaint Louverture and the American Civil War: the promise and the peril of a Second Haitian Revolution. Philadelphia, University of Philadelphia Press. 
Código Criminal do Império do Brazil annotado com os atos dos poderes Legislativo, Executivo e Judiciário, que têm alterado e interpretado suas disposições desde que foi publicado, e com o cálculo das penas em todas as suas aplicações por Araújo Figueiras Júnior (Bacharel em Direito), 1876, Rio de Janeiro, Eduardo e Henrique Laemmert, 2a . Edição cuidadosamente revista e aumentada com os atos dos Poderes supra-referidos, expedidos depois da $1^{\text {a }}$. Edição.

Couceiro, L. A.

2003 Bumerangue encapsulado: um estudo sobre a construção social da subjetividade numa cidade escravista, Rio de Janeiro, c.1860-c.1888. Rio de Janeiro, 7Letras.

CUNHA, M. C. da

2009 "Sobre os silêncios da lei (com posfácio sobre Henry Koster)". In

Cultura com aspas e outros ensaios. São Paulo, Cosac Naif, pp. 133-156.

EISENBERG, P. L.

1977 Modernização sem mudança: a indústria açucareira em Pernambuco, 1840-1910. Rio de Janeiro, Campinas, Paz \& Terra, Unicamp.

FARIA, S. C.

1997 "Identidade e comunidade escrava: um ensaio". Tempo-Revista do Departamento de História da UFF, n.22, v.11: 133-157.

Farias, J. B.; Spares, C. E. L. e Gomes, F. dos S.

2005 No labirinto das nações: africanos e identidades no Rio de Janeiro, século XIX. Rio de Janeiro, Arquivo Nacional.

FICK, C.

1990 The making of Haiti: the Saint Domingue Revolution from below. Knoxville, The University of Tennessee Press.

Florentino, M. e GÓES, J. R.

1997 A paz. das senzalas: famílias escravas e tráfico Atlântico, Rio de Janeiro, c.1790-c.1850.

Rio de Janeiro, Civilização Brasileira.

FrANCO, M. S. de C.

1969 Homens livres na ordem escravocrata. São Paulo, IEB/USP.

GALLOWAY, J. H.

1968 "The sugar industry of Pernambuco during the Nineteenth Century". Annals of the Association of American Geographers, v.58, n.2: 285-303. 
1971 "The last years of slavery on the sugar plantations of Northeatern Brazil". Hispanic American Historical Review, n.51: 586-605.

GeGgus, D. (org.)

2001 The impact of Haitian Revolution in the Atlantic World. Columbia, University of South Carolina Press.

GenOvese, E.

1979 O mundo dos senhores de escravos: dois ensaios de interpretação. Rio de Janeiro, Paz \& Terra.

GLUCKMAN, M.

1965 The ideas in Barotse Jurisprudence. New Haven e Londres, Yale University Press.

GOFFMAN, E.

1988 Estigma: notas sobre a manipulação da identidade deteriorada. Rio de Janeiro, LTC, $4^{a}$ Edição.

Gomes, F. dos S.

2002 "Experiências transatlânticas e significados locais: ideias, temores e narrativas em torno do Haiti no Brasil escravista”. Tempo-Revista do Departamento de História da UFF, v.7, n.13: 209-246.

GRINBERG, K.

1994 Liberata, a lei da ambiguidade: as ações de liberdade da Corte de Apelação do Rio de Janeiro no século XIX. Rio de Janeiro, Relume-Dumará.

GRINBERG, K.

2002 O fiador dos brasileiros: cidadania, escravidão e direito civil no tempo de Antonio Pereira Rebouças. Rio de Janeiro, Civilização Brasileira.

GUIMARÃES, E. S.

2006a Múltiplos viveres de afrodescendentes na escravidão e no pós-emancipação: família, trabalho, terra e conflito (Juiz de Fora-MG, 1828-1928). São Paulo, Juiz de Fora, Annablume, Funalfa Edições.

2006b Violência entre parceiros de cativeiro: Juiz de Fora, segunda metade do século XIX. São Paulo, Annablume, Fapesp.

Hobsbawm, E. J. e Rudé, G.

1982 Capitão Swing: a expansão capitalista e as revoltas na Inglaterra do início do século XIX. Rio de Janeiro, Francisco Alves. 
JAMES, C. L. R.

2000 Os jacobinos negros: Toussaint L'Ouverture e a revolução de Santo Domingo. Rio de Janeiro, Boitempo.

KAYE, A.

2008 Joining Places: slave neighborhoods in the Old South. Chapel Hill, University of North Carolina Press.

KaYe, H. J. e MCClELland, K. (eds.)

1990 E. P. Thompson: critical perspectives. Cambridge, Oxford, Polity, Basil Blackwell.

KLEIN, H. S.

2009 "American slavery in recent Brazilian scholarship, with emphasis on quantitative Socio-Economic Studies (Review Essay)". Slavery \& Abolition, n.30, v.1: 111-133.

LAMOUNIER, M. L.

1988 Da escravidão ao trabalho livre: a Lei de Locação de Serviços de 1879. Campinas, Papirus.

LARA, S. H.

1995 'Blowin' in the wind: E. P. Thompson e a experiência negra no Brasil". Projeto História, São Paulo, PUC, n.12: 43-56.

LARA, S. H.

1988 Campos da violência: escravos e senhores na capitania do Rio de Janeiro, 1750-1808. Rio de Janeiro, Editora Paz \& Terra.

LOURENÇO, T. C. P.

2010 O Império dos Souza Breves nos oitocentos: política e escravidão nas trajetórias dos comendadores José e Joaquim de Souz̧a Breves. Niterói, dissertação, UFF, 188 pp.

MACHADO, M. H. P. T.

1994 O Plano e o pânico: os movimentos sociais na década da abolição. Rio de Janeiro, Editora UFRJ, Edusp.

1987 Crime e Escravidão: trabalho, luta e resistência nas lavouras paulistas, 1830-1888. São Paulo, Brasiliense.

1988 "Em torno da autonomia escrava: uma nova direção para a história social da escravidão”. Revista Brasileira de História, v.8, n.16: 143-160. 
MALHeiro, A. M. P.

1944 A escravidão no Brasil: ensaio histórico-jurídico-social, parte $1^{a}$. (Jurídica), Direito sobre os escravos e libertos. São Paulo, Cultura.

MANN, K.

2001 "Shifting paradigms in the study of the African Diaspora and Atlantic History and Culture". Slavery \& Abolition, v.22, n.1: 3-21.

MARquese, R. de B.

2004 Feitores do corpo, missionários da mente: senhores, letrados e o controle dos escravos nas Américas, 1660-1860. São Paulo, Companhia das Letras.

2013 “As desventuras de um conceito: capitalismo histórico e a historiografia da escravidão brasileira”. Revista de História, 169, jul.-dez: 223-253.

2010 "O Vale do Paraíba cafeeiro e o regime visual da segunda escravidão: o caso da fazenda Resgate". Anais do Museu Paulista, v.18: 83-128.

MENDONÇA, J. M. N.

1999 Entre a mão e os anéis: a Lei dos Sexagenários e os caminhos da abolição no Brasil. Campinas, Editora da Unicamp, Cecult.

Miller, J. C.

2004 "Retention, reinvention, and remembering identities through enslavement in Africa and under slavery in Brazil". In Curto, J. C. e Lovejoy, P. E. Enslaving connections: changing cultures of Africa and Brazil during the Era of Slavery. New York, Humanity Books, pp. 81-124.

MOOREJR., B.

1967 Social origins of democracy and dictatorship. Boston, Beacon Press.

MORGAN, P. D.

1988 "Task and gang systems: the organization of labor on New World plantations". In InNES, S. (ed.), Work and Labor in Early America. Chapel Hill, Unc Press, pp. 189-219.

1997 "The cultural implications of the Atlantic slave trade: African regional origins, American destinations and new world developments". Slavery \& Abolition, n.18, v.1: 122-145.

MORRIS, C.

1998 "The articulation of two words: the master-slave relationship reconsidered". The Journal of American History, v.85, n.3: 982-1007. 
Moura, D. A. S. de

1998 Saindo das sombras: homens livres no declínio do escravismo. Campinas, Fapesp, Centro de Memória/Unicamp.

NABUCO, J.

1995 Minha formação. Porto Alegre, Editora Paraula.

Oliveira, J. A. C. de

1988 Minha meninice \& outros ensaios. Recife, Fundação Joaquim Nabuco/Editora Massangana.

Oliveira, L. R. C. de

1992 "Comparação e interpretação na antropologia jurídica". Anuário Antropológico, n.89: 23-46.

Oliveira, M. I. C. de.

1995/1996 "Viver e morrer no meio dos seus: nações e comunidades africanas na Bahia do século XIX”. Revista Usp, n.28: 175-193.

PARÉS, L. N.

2006 A formação do Candomblé: história e ritual da nação jeje na Babia. Campinas, Editora da Unicamp.

2005 "O processo de crioulização no Recôncavo baiano (1750-1800)". Afro-Asia, CEAO, UFBA, v.33: 70-101.

PENA, E. S.

2001 Pajens da casa imperial: jurisconsultos, escravidão e a Lei de 1871. Campinas, Editora da Unicamp, Cecult.

REIS, J. J.

2003 Rebelião escrava no Brasil: a bistória do levante dos malês em 1835. São Paulo: Companhia das Letras, edição revista e ampliada.

REIS, J. J. e SILVA, E.

1989 Negociação e conflito: a resistência escrava no Brasil escravista. São Paulo, Companhia das Letras.

RODRIGUES, J.

2005 De Costa a Costa: escravos, marinheiros e intermediários do tráfico negreiro de Angola ao Rio de Janeiro (1780-1860). São Paulo, Companhia das Letras.

2000 O infame comércio: propostas e experiências no final do tráfico de africanos para o Brasil (1800-1850). Campinas, Editora da Unicamp, Cecult. 
SCOTT, R. J.

1991 Emancipação escrava em Cuba: a transição para o trabalbo livre, 1860-1899. Rio de Janeiro, Campinas, Paz e Terra, Editora da Unicamp.

SIGAUD, L.

2007 "Se eu soubesse": os dons, as dívidas e suas equivalências". Ruris, n.1, v.2: $123-153$

2004 "Armadilhas da honra e do perdão: usos sociais do direito na mata pernambucana". Mana, n.10, v.1: 131-163.

1999 "Les paysans et le droit: le mode juridique de règlement des conflits". Information sur les sciences sociales, n.38, v.1: 113-147.

1996 "Direito e coerção moral no mundo dos engenhos". Estudos Históricos, n.18: 361-388.

1977 “A idealização do passado numa área de plantation”. Contraponto, v. II: 115-126.

Silva, E.

1984 Barões e escravidão: três gerações de faz̧endeiros e a crise da estrutura escravista. Rio de Janeiro, Brasília, Nova Fronteira, INL.

SLENES, Robert W.

1999 Na senzala, uma flor: esperanças e recordacõoes na formação da família escrava-Brasil Sudeste, século XIX. Rio de Janeiro, Nova Fronteira.

1991-1992 ““'Malungu, Ngoma vem!”: África coberta e descoberta do Brasil [sic: leia-se "no"]". Revista USP, n.12: 48-67.

1995-1996 “As provações de um Abrão africano: a nascente nação brasileira na viagem alegórica de Johann Moritz Rugendas". Revista de História da Arte e Arqueologia, n.2, Ifch-Unicamp: 271-536.

SoAres, C. E. L. e GoMes, F. dos S.

2002 "Sedições, haitianismo e conexões no Brasil: outras margens do Atlântico negro", Novos Estudos Cebrap, n.63: 131-144.

STEIN, S. J.

1990 Vassouras: um município brasileiro do café. 1850-1890. Rio de Janeiro, Nova Fronteira.

Thompson, E. P.

1987 Senhores e caçadores: a origem da Lei Negra. Rio de Janeiro, Paz \& Terra. 
1971 "The moral economy of the English crowd in the Eighteenth Century". Past \& Present, n.50: 76-136.

ThORNTON, J. K.

1991 “African dimensions of the Stono rebellion". The American Historical Review, v.96, n.4: 1101-1113.

Tomich, D. T. e Zeuske, M. (eds.)

2008 The second slavery: mass, slavery, world-economy, and comparative microbistories. Fernand Braudel Center Review. v.XXXI, n.2.

Tratado proposto a Manuel da Silva Ferreira pelos seus escravos durante o tempo em que se conservaram levantados (c. 1789), in REIS, J. J. e SILVA, E. 1989 Negociação e conflito: a resistência escrava no Brasil escravista, São Paulo, Companhia das Letras: 123-124.

VERSIANI, F. R.

2000 "Os escravos que Saint- Hilaire viu”. História Econômica e História de Empresas, n.1, v.3: 7-42;

WEBER, M.

1997 Economia y sociedad: esbozo de sociología comprensiva. México, Fondo de Cultura Económica, 11․ Reimpresión.

WissenbaCH, M. C. C.

1998 Sonhos africanos, vivências ladinas: escravos e forros em São Paulo (1850-1880). São Paulo, Hucitec, História Social-usP.

WOLF, E. W.

2003 "Encarando o poder: velhos insights, novas questões". In FELDMAN-BianCO, Bela e LiNs RiBEIRO, Gustavo (orgs.), Antropologia e poder: contribuições de Eric R. Wolf. Brasília, São Paulo, Campinas, Editora Unb, Imprensa Oficial do Estado de São Paulo, Editora da Unicamp, pp.325-343.

WoOD, P. H.

1996 Black majority: negroes in colonial South Carolina from 1670 through the Stono Rebellion.

Nova York, Londres, W. W. Norton \& Company.

ZAECK, N.

2003 "Voices and silences: the problem of slave testimony in the English West Indian Law Court". Slavery \& Abolition, n.3, v.24: 24-39. 


\title{
Demands, rights and understandings of "Justice": a case study of the slave society of the Empire of Brazil
}

\begin{abstract}
In this text I analyze a case occurred in 1872 and that gave birth to a criminal process, in which slaves of the Monte Verde farm, São Fidélis (Rio de Janeiro), killed and dismembered the slaves' foreman Tertuliano Guerra. I argue that the slaves were aware that taking the matter to "Justice", indulging after committing a murder, would be a way of embarrassing their masters and having their demands met. I use analytical strategies such as interpretation of other types of situations in which slaves eventually became aware that using the justice was an interesting way to assert their rights inscribed in laws, and not only the customary ones.
\end{abstract}

KEYWORDS: Slave Labor and Justice, Crime, Law and Moral Control, Anthropology of Slavery.

Recebido em setembro de 2013. Aceito em setembro de 2015. 